\title{
Losing Control? Inequality and Social Divisions in Oslo
}

\section{TERJE WESSEL}

[Paper first received, February 2001; in final form, May 2001]

ABSTRACT The debate on inequality and social divisions in Western cities has been dominated by three positions - the polarization thesis, the 'skills mismatch' thesis and a specific European approach emphasizing the significance of welfare state structures. These three positions are examined with data from Oslo, Norway. It is shown that although income inequality has increased, there is no consistent pattern of social divisions. The evidence provides support both for the polarization and the mismatch thesis, dependent on the unit of analysis and the group in question. It is difficult to spot influences of the welfare state in these data, and it is argued that rising inequality, contrary to service provision, poverty and segregation, approaches a 'closed process'. Increased earnings at the very top, however, may be explained in terms of social networks.

\section{Introduction}

Research on economic inequality in Western cities has shown striking distributive changes, inspiring a new set of theories. At present, 'the polarization thesis' seems to hold the centre stage and has thus replaced the 'Kuznets hypothesis' that dominated research on development and inequality in the 1960s and 1970s. According to Simon Kuznets (1955), income inequality would first increase as a society became industrial, then peak, and finally level off and decline as technological and institutional change progressed. The polarization argument turns this relationship upside down: instead of the inverted U-shaped 'Kuznets curve', we have what Bennett Harrison and Barry Bluestone (1988) termed 'The great U-turn'. Whereas the former curve was predicated on a dualism between traditional and modern sectors of the economy, the latter is derived from a suspected dualism within the modern sector, that is, within the new service economy. Proponents of the polarization thesis argue that global economic restructuring leads to a growing upper tier of high-skilled service jobs with high wages, which in turn contributes to a vast expansion of low-skilled or unskilled, low-wage, often temporary and part-time service jobs. In some versions, it is also an explicit assumption that mechanisms of supply and demand are significantly disturbed through large-scale ethnic immigration (Sassen, 1991, 1995, 1998). In any case, with or without high levels of immigration, on this view there is no straightforward training solution to the problem of increasing inequality. Major

Terje Wessel, Department of Sociology and Human Geography, Box 1096, 0316 Blindern, Norway. E-mail: terje.wessel@sgeo.uio.no 
improvements in education might improve the material and social conditions of some groups, but it will not remove the main sources of a resurgent structural inequality.

As repeatedly noted in the literature, 'the skills mismatch thesis' offers a different explanation. Here, increasing inequality results from elimination of jobs under the pressure of computer-aided production and foreign labour competition. The central idea is that the post-industrial economy, through a simple play of supply and demand, raises the return to professional competence and leaves behind the low-skilled, the unskilled and, in some cases, the less-experienced. By implication, the prescription is to promote education and vocational training, thus achieving the double effect of higher productivity and a lower premium on high skills (Kasarda, 1989; Friedrichs, 1993).

Given the American origin of both theses, it is not surprising that European scholars tend to emphasize the need for more context-sensitive approaches. A favourite line of criticism, especially targeted at the polarization thesis, addresses the lack of attention to welfare policies: "The outcomes of global economic restructuring are essentially variable, depending on the ways in which restructuring processes are mediated within different states" (Hamnett, 1996, p. 1424). At issue in particular are questions of redistribution and collective consumption. First, it is suggested that certain states are able to offset the drive towards increasing economic inequality. This is accomplished partly through economic redistribution and partly through a generous provision of welfare services such as health, education, housing, childcare and home help (cf. Hamnett, 1994a; Buck, 1986; Burgers, 1996; Hamnett, 1996; Kloosterman, 1996; Murie \& Musterd, 1996; Fainstain, 1997; Hamnett \& Cross, 1998; Murie, 1998; Andersen \& Clark, 2001). A second claim relates to creation of jobs and industrial policies. Juhani Lehto (2000), among others, argues that the welfare state is a major provider of jobs in European cities. He adds that these jobs are female-dominated, and that the dual-career family has been vastly enhanced by public care services. Other urban analysts have maintained that nationstates shape urban development by influencing the whole labour market (Silver, 1993; Burgers, 1996; Hamnett, 1996). ${ }^{1}$

At the base of these claims is a concern with specificity, variations and agency. A key point is that cities are embedded in nations with specific ideological and political attributes, whether these attributes are clustered into 'regimes' or not. Most authors assume that European public authorities have wider powers to restrain processes of social division than the US welfare state. There is also a recurrent tendency to put Scandinavia at the top of a 'welfare state hierarchy'. In the words of Lehto (2000, p. 113): "It might be expected that the impact of the welfare state on cities would be most visible in Scandinavia".

The purpose of this paper is to examine contemporary distributive changes in Oslo, ${ }^{2}$ Norway. Two principal questions are raised: (1) How do patterns of economic inequality and social differentiation fit with the theses outlined above? (2) Do the trends in Oslo diverge from those in the whole of Norway? In addition, and following up earlier research, the paper attempts to address a couple of subsidiary questions. Is the extent and direction of change dependent on the inclusion of social groups such as students, non-Western immigrants and part-time workers? Does capital income constitute the only source of distributive change?

My ambition is thus largely empirical, although I will provide some thoughts as to why certain classic distributive concerns are more sensitive to economic pressure than others. In all manner of ways, Oslo ought to make an interesting case. Not only is Scandinavia a recurrent example in the literature, there is also an emerging recognition that Norway, with abundant oil revenues, has been able to finance itself out of dilemmas facing social democracy elsewhere. Following this logic, a recent analysis of the 'jobs-equality' trade-off in the Nordic countries deliberately omits Norway (Esping-Andersen (1998).

The next section discusses some methodological distinctions and implications. After that, I turn to the existing evidence on income inequality in Norway, succeeded by a description 
of the data sources and the data. The two following sections explore changes in inequality and social divisions in Oslo, compared to the whole of Norway. Results are then summarized and discussed.

Unfortunately, a lack of specified data makes it impossible to analyse service-sector divide, quality of jobs and turnover in the bottom end of the labour market. Nor is it possible to estimate the effects of taxes and transfers. Overcoming these obstacles to empirical research is one aim of an ongoing research project. Another aim is to identify effects of inventions (roughly 'creativity') and local entrepreneurial activity on social equity. This sort of analysis seems to call upon rather unusual combinations of thought. The present paper, however, makes no claim of reaching beyond the current state of urban theory.

\section{Concepts and Empirical Implications}

There are a number of complexities in the debate on social polarization, skills mismatch and urban marginality. One particular source of misconception concerns the distinction between inequality and polarization. It is elementary knowledge that inequality comes in many geometrical forms, such as 'the pyramid', 'the onion' and 'the hour glass' (cf. Pahl, 1988). A more astonishing theoretical observation is that increasing inequality does not necessarily imply increasing polarization, and vice versa. A concentration of formerly middle class groups at higher and lower levels will usually coincide with rising income inequality, but it is not difficult to construct anomalies. It has been demonstrated, beyond doubt, that the middle of a distribution can be 'hollowed out' (i.e. polarization) while simultaneously improving the widely accepted Lorenz criterion (i.e. increasing equality). More generally, the notion of polarization has to do with clustering of attributes, whereas the notion of inequality is independent of sub-group frequencies (Levy \& Murnane, 1992; Esteban \& Ray, 1994; Wolfson, 1994). The economic principle underlying the Lorentz criterion (the Dalton principle of transfers) states that "starting from any distribution of income, any transfer of income from an individual to one richer than him must increase inequality" (Esteban \& Ray, 1994, p. 826).

These basic features clearly affect linguistic practices and what we perceive as enlightening representations. When a distribution is polarized, we tend to assume that the dominating groups ('rich' and 'poor') are both internally homogeneous and conflictingly opposed to each other (Esteban \& Ray, 1994). Possibly for this reason, there is an increasing consensus that polarization is a redistribution of people or jobs, and not of income. Hamnett and Cross (1998), following the OECD and Kloosterman (1996), have summarized the point as follows:

The fact that the rich may be getting richer and the poor poorer (or richer but at a slower pace than the high earners) is not evidence of earning polarisation but of greater inequality. There is a major difference between arguing that the richer are getting richer and the poor poorer and between arguing that there are more rich and more poor. One trend may be occurring or both or neither, and it is theoretically and practical important to determine which trends are occurring if we are to understand processes of social change in global cities and, hopefully, to make interventions in policy. (p. 660)

This conceptual distinction, however, is often ignored in the globalization literature. Manuel Castells, for instance, uses a rather relaxed terminology. The new system is characterized, he says, by a "tendency to increased inequality and polarization, namely the simultaneous growth of both the top and the bottom of the social scale" (Castells, 1998, p. 344). On other occasions (p. 132), the image is significantly different: "Furthermore, inequality has taken the shape of polarization: the richer families increased their average annual income the fastest, while the 
poorer ones saw their income decline the most". Much of the same is true with the theoretical framework of Saskia Sassen. She usually refers to 'polarization' as a differentiation of jobs or, secondarily, of social groups. But we also encounter passages where the unit of measure is income, share of income or wage level (e.g. Sassen, 1998, p. 47).

I will not press this point any further. Without in any way reducing the authority of Castells and Sassen, I rather prefer the restricted definition suggested by Hamnett and Cross. It is also appropriate, I think, to respect the intuition that 'polarization' is closely related to human behaviour and feelings of alienation. The OECD proposal (cf. Kloosterman, 1996) could easily be extended in such a direction, for instance by requiring some sort of antagonism between structurally opposed groups. But for the time being, analysing distribution characteristics, I will settle for a simple definition based on numbers of people. 'Polarization', or more suitably, 'symmetric polarizaton', denotes a process where parts of the middle population disappear into the top and the bottom category. As indicated above, this is the pattern of change proposed by polarization theory. 'Asymmetric polarization', however, occurs when only one of the end categories increases at the expense of the middle. The third focal concept, 'income inequality', refers to extent of dispersion between levels of income. Accordingly, I adopt a terminology where symmetric and asymmetric polarization are dynamic concepts, whereas inequality describes a condition. ${ }^{3}$

By my assessment, the skills mismatch thesis presents a coherent equilibrium model of asymmetric polarization. The thesis suggests, sometimes implicitly, that a rising demand for skilled labour is succeeded by a growth in the relative number of workers with such skills. Hence, on this view a large proportion of the population is adversely affected by demand factors such as technological change, liberalization of international trade and heightened competition from newly industrializing countries. It is important to notice that 'professionalization' connotes a structurally different phenomenon, where a large part of the middle population is swelling, and where the size-factor is related to qualifications alone. Some of the literature, particularly a paper by Chris Hamnett (1994b), presents professionalization as a competing alternative to social polarization. Considering later arguments, however, we are left with a more complicated picture. There is now a greater awareness of the distinction between indicators based on education or professional skills and indicators based on material resources. It is also acknowledged that unemployment, including early retirement, is a crucial factor (cf. Burgers, 1996; Hamnett, 1996). The case for a specific European trajectory is brought further into doubt by evidence of asymmetric earnings polarization in London (Hamnett \& Cross, 1998).

It is thus a straightforward task to identify two sets of implications. The polarization thesis implies a U-shaped distribution relative to the baseline: a fairly symmetric growth at the top and the bottom. The skills mismatch thesis posits a strong growth at the upper end of the distribution, with a stagnant pool of people/jobs at lower positions. As for the third view, which is a loose collection of political economy arguments, we will have to rely on a selective interpretation. Some empirical results emerging from political-institutional frameworks are strikingly similar to those predicted by mismatch theory. However, following Lehto (2000), and using an ideal type methodology, we might expect a fattening middle in Scandinavian cities (see also Pahl, 1988; Hamnett, 1996; Esping Andersen, 1993). A related assumption is that social democratic 'regimes' are able and willing to counteract market inequality. Proponents of the polarization and mismatch perspectives, in contrast, tend to use the same indicators of rising inequality (the Gini coefficient, Theil's index and the coefficient of variation) as supporting evidence for their thesis. As pointed out by Handcock et al. (1994), the relative accuracy of these explanations can only be determined on the basis of descriptive methods and qualitative work. Section four of this paper explains one such method, 'the decile approach'. 


\section{Economic Development and Income Distribution in Norway}

Norwegian politics and society is often, and correctly, defined in terms of egalitarian traditions. Overall, there is a view that equality contributes to welfare, and also that policies of redistribution can be growth-enhancing. A basic assumption holds that policies characterized by solidarity create macro-economic efficiency more than they create inefficiency due to 'deadweight losses'. Some of the involved policies fit the proposition of a 'Scandinavian model' whereas others are national idiosyncrasies: compared to the rest of Scandinavia, Norway is distinguished by a continuous effort to pursue collective agreements between capital, labour and the state. The high point of such corporatism was probably reached in the mid-1970s (Dølvik et al., 1997), but as late as 1992 the major social partners (the government and the federations of trade unions and employers) adopted a re-negotiated approach, the so-called 'Solidarity Alternative'. From 1987 on, Norway had witnessed an unprecedented acceleration of unemployment, reaching $6.5 \%$ in 1993 (in excess of $11 \%$ when people in active labour market measures and people transferred to pension programmes are counted). The new pact aimed at improving the competitiveness of mainland industry through a combination of moderate wage growth, sound budgetary policies and stable exchange rates vis-à-vis trade partners. Thus, unlike other European nations, Norway tried to cope with exogenous pressure by a regeneration of 'old' policies. ${ }^{4}$ According to an employment commission, which submitted its report in 1992 (NOU, 1992), the 'Solidarity Alternative' could potentially bring down unemployment to around $3.0-3.5 \%$ within 5 years.

In several ways, the 'Solidarity Alternative' delivered. There is substantial consensus that the cooperation framework helped pulling the economy out of a prolonged slump that followed the oil price collapse in 1986. Traditional exports increased, competitiveness improved and private sector growth raised the employment rate to almost $80 \%$ of the working-age population, among the highest in the OECD area (OECD, 1999). Towards the end of 1998 the official employment rate fell below 3.0\% (OECD, 1999), leading to worries about human capital deficits.

It is equally important that people holding jobs improved their position. Until 1995 the wage agreements were moderate, but because of declining interest rates and low inflation, most workers still benefited from growing real wages. During 1996-1997 inflation remained low, but subsequently an accumulated pressure resulted in pay rounds far beyond the criteria of the 'Solidarity Alternative'. In a situation with sound public finances, soaring company profits, golden deals for top leaders, recovering labour markets and huge dividends to shareholders, the support and legitimacy of moderate wage policies were crumbling.

A third effect of the social pact, and indeed of the whole corporatist system, has been to curb a pressure towards wage dispersion. Measured in comparative terms, the norm being male industrial workers, low-wage employees seem to have gained from the 1992 agreement, as they also did from low-wage policies in the 1970s and 1980s. The private sector as a whole was marked by a fairly stable level of inequality during 1975-1996, possibly with a slight dispersion. The public sector, however, is quite another matter. Neither the 'Solidarity Alternative' nor the preceding settlements could prevent a strong downward trend for most occupational groups, especially those with university education (Høgsnes, 1999). Altogether, neglecting sector differences, wage inequality in Norway declined from 1980 to 1995 (Barth \& Kongsgården, 1996; St.meld., 1998-1999). As phrased by a foreign observer, Norway seems to be 'going against the wind' (Freeman, 1997, p. 44). But this is not solely a question of coordinated and centralized regulation: one could argue that the aggregate result has a rather accidental form (Høgsnes, 1999).

In a broader context, when all income components are counted, the promise of increasing 
economic equality has been difficult to achieve. Contrary to a common impression, the distribution of household incomes remained fairly constant during the 1960s and 1970s (Rødseth, 1977; NOU, 1993, Strøm et al., 1993). Even more surprising is the fact that income inequality for all households (adjusted for economies of scale) declined from the early 1980s until 1988. This was a period of neo-liberal winds and state withdrawal, and it is often assumed that new market-oriented policies instantly triggered greater differentials. A more qualified assumption, I suggest, is that institutional changes produced both transitional and lasting outcomes. The idea of a causal lag should not be accepted without further examination, but at least it makes sense that income differences increased during 1989-1996 (Epland, 1998). A breakdown across income components indicates that taxes and transfers, although with certain exceptions, barely contributed to a wider distribution. Capital income was, by far, the major contributor to rising inequality (Epland, 1998). The most important source of capital income, dividends to shareholders, was exempted from personal taxation in the early 1990s, which immediately affected household and business decisions. Within 4 years, from 1992 to 1996, dividends grew from 2 billion NOK to 11 billion NOK (Epland \& Kirkeberg, 1999). To give a crude idea of the subsequent effects, suffice it to say that almost $90 \%$ of such earnings are taken by the top decile (St.meld., 1998-1999).

The government in Norway has responded to the distributive changes both in word (e.g. St.meld., 1998-1999) and act (e.g. tax adjustments in the budget). In a circular vein, these discussions and proposals based on statistics generate new statistics. Thus, for the first time, we can now present comprehensive and reliable data on regional income differences. The wage component is, for several reasons, particularly interesting. Given that Oslo and the other major cities are far ahead in terms of economic restructuring, one would expect a trend towards wage dispersion in these places that is not apparent at the national level. The possibility of such a discrepancy has never been investigated, and has even been ridiculed by a leading investor and editor (Hegnar, 1999).

There are also elements of uncertainty in the analyses conducted so far. Students, for example, make up about $7.5 \%$ of the adult population in Oslo, and it is a tricky question whether they should be counted or not. Such issues are dealt with here according to a principle of complement: where there is uncertainty, a different alternative has been chosen compared to those in earlier reports.

\section{Data and Methods}

I use two sets of data, of which the first is a series of calculations based on the National Survey of Income and Wealth. One advantage with this source is that all types of income are counted-wages, self-employment incomes, capital incomes and transfers. The period of observation is 1986-1996, and the unit of observation is the household, defined as a collection of individuals who share the same housing unit. Equivalent income per household member is calculated after adjusting household income for household size, where the adjustment reflects certain assumptions about household economies of scale $(E=0.5)$. Income after tax includes all regular types of income minus negative transfers and taxes.

The second set of data rests on a coupling of three public registers: the register of income, the register of employment and the register of immigration. All individuals who satisfy the computation requirements, and who are properly registered in Oslo/Norway, are counted. This gives a unique opportunity to trace small differences between the municipality of Oslo and Norway as a whole, as well as small changes at either level. A weakness, though, is that only 5 years are covered, 1993-1998. It should further be noted that only wages, incomes from self-employment and capital incomes are included. The income register has no information on households, and it would clearly be misleading to attribute transfers such as social 
security benefit and rent allowance to individuals. A third deficiency springs from the nature of the data source: payments received 'off the books' are of course not included.

Inequality is measured by shares (deciles) of the total income, average income by decile and the Gini coefficient. I have also chosen a breakdown at the decile level in the analysis of social differentiation. The fraction of households/workers falling into each decile is tracked over time by deflating the cut-off points (in money terms) by, first, the general rate of inflation and, second, the change in median income. Neither of these deflators is sufficient alone, but together they give a proper picture of polarization/depolarization (cf. Handcock et al., 1994; Kloosterman, 1996, Hamnett \& Cross, 1998). Medians do not reflect growth at the upper and/or lower level, whereas the general rate of inflation has a somewhat 'contingent' character: in periods of pronounced wage inflation, there will be a disproportionate growth of workers in the top deciles. If, however, price inflation exceeds the increase in real wage, a converse distribution emerges (Hamnett \& Cross, 1998).

\section{Income Inequality in Oslo}

I will first turn to the distribution of income. As already noted, increasing inequality does not provide a relevant test of the polarization and the mismatch theses. Measures of inequality are, nevertheless, important supplementary information. Both theses perceive rising inequality as a product of exogenous events, largely untouched by conventional redistributive policies (taxes and transfers). Concerning the welfare state thesis, the most detrimental outcome would probably be parallel trends of polarization and rising inequality. It would also be unfavourable if a regressive redistribution of income is recorded at the household level. The Norwegian redistributive system has several equalizing mechanisms which are supposed to weaken the relationship between low pay in the labour market and low family income. Even more important is a rapid increase in full-time employment among women (St.meld., 1998-1999), which should be seen against the backdrop of extensive childcare and fairly generous parental rights (earnings compensation and parental leave).

The data analysed here do not capture the effects of income replacement and taxation, but looking at inequality figures, there can be no doubt that these are hard times for politicians promoting 'Norwegian exceptionality'. Counting all households, the Gini coefficient for income after tax increased by $35 \%$ in Oslo and $16 \%$ in the whole of Norway during 1986-1996 (Table 1, panel 1). A comparison of averages by decile, gives the impression of abnormal changes; what I have recently termed 'a social democratic nightmare' (Wessel, 2000, p. 1958): the average income of the top decile in Oslo increased by 60\% between 1986 and 1996, compared to a decrease of $17 \%$ in the bottom decile (panel 3). However, one should be careful not to take these figures at face value. One relevant objection is that tax changes ${ }^{5}$ have contributed to a more effective registration of incomes among well-capitalized households. While this is a probable source of error, there is no evidence that the data are seriously flawed. The National Survey of Income and Wealth has been widely used in public reports, and it forms an indispensable basis for political discussions and distributive proposals. Most importantly, one should not forget that galloping dividends run parallel to galloping values in the stock market. According to St.meld. (1998-1999), a suitable measure might be to merge dividends and share capital into one fictitious figure. For my part, I believe such a construction would confirm the depiction of significant changes.

A second objection might be that part-time work among students, as well as the number of students, has increased substantially since the late 1980s, thus contributing to widening inequalities. If that is the case, the welfare consequences are obviously of limited extent. Due to the size of the samples, this possibility cannot be examined through a dissection of distributive effects, but fortunately the samples allow separate analyses for some of the largest 
Table 1. Trends in inequality measures in Oslo and Norway, 1986 and 1996, income after tax at the household level, deflated to NOK $1986(E=0.5)$

\begin{tabular}{|c|c|c|c|c|c|c|}
\hline & \multicolumn{2}{|c|}{1986} & \multicolumn{2}{|c|}{1996} & \multicolumn{2}{|c|}{ Percentage change } \\
\hline & Oslo & Norway & Oslo & Norway & Oslo & Norway \\
\hline (1) Gini coefficient & 0.249 & 0.222 & 0.337 & 0.257 & 35.3 & 15.8 \\
\hline $\begin{array}{l}\text { Standard deviation } \\
\text { (2) Share of income }\end{array}$ & 0.007 & 0.002 & 0.017 & 0.004 & & \\
\hline Decile 1 & 3.7 & 4.1 & 2.7 & 3.7 & -27.0 & -9.8 \\
\hline Decile 2 & 5.3 & 6.1 & 4.9 & 5.6 & -7.5 & -8.2 \\
\hline Median & 9.0 & 9.1 & 7.9 & 8.8 & -12.2 & -3.3 \\
\hline $\begin{array}{l}\text { Decile } 10 \\
\text { (3) Average by decile }\end{array}$ & 19.7 & 18.6 & 27.9 & 21.7 & 41.6 & 16.7 \\
\hline Decile 1 & 61523 & - & 51083 & - & -17.0 & - \\
\hline Decile 10 & 329836 & - & 526463 & - & 59.6 & - \\
\hline $\begin{array}{l}\text { All } \\
\text { (4) Marginal values }\end{array}$ & 167160 & - & 188475 & - & 12.8 & - \\
\hline $\mathrm{P} 10$ & 78829 & - & 78763 & - & -01 & - \\
\hline P 50 & 157259 & - & 158069 & - & 0.5 & - \\
\hline P 90 & 256673 & - & 280121 & - & 9.1 & - \\
\hline
\end{tabular}

Source: The National Survey of Income and Wealth.

groups. Table 2 is based only on households that include a male or female 'head' in full employment. The concept of income is 'market income', which includes wages, incomes from self-employment and capital incomes. By leaving out transfers, I hope to obtain a direct reflection of economic change.

In part, the data validate the interpretation given above. We see from Table 2, panel 1

Table 2. Trends in inequality measures in Oslo and Norway, 1986 and 1996, market incomes (wages, incomes from self-employment and capital incomes) among households with a fully employed 'head', deflated to NOK $1986(E=0.5)$

\begin{tabular}{|c|c|c|c|c|c|c|}
\hline & \multicolumn{2}{|c|}{1986} & \multicolumn{2}{|c|}{1996} & \multicolumn{2}{|c|}{ Percentage change } \\
\hline & Oslo & Norway & Oslo & Norway & Oslo & Norway \\
\hline (1) Gini coefficient & 0.278 & 0.245 & 0.363 & 0.292 & 30.6 & 19.2 \\
\hline \multicolumn{7}{|l|}{ (2) Share of income } \\
\hline Decile 1 & 3.3 & 3.9 & 2.4 & 3.1 & -27.3 & -20.5 \\
\hline Decile 2 & 5.1 & 5.7 & 4.3 & 5.2 & -15.7 & -8.8 \\
\hline Median & 8.6 & 8.7 & 7.7 & 8.4 & -10.5 & -3.4 \\
\hline Decile 10 & 21.7 & 19.7 & 29.2 & 23.5 & 34.6 & 19.3 \\
\hline \multicolumn{7}{|l|}{ (3) Average by decile } \\
\hline Decile 1 & 57622 & 57669 & 67949 & 72494 & 17.9 & 25.7 \\
\hline Decile 10 & 380778 & 291019 & 824239 & 553164 & 116.5 & 90.1 \\
\hline All & 175803 & 147516 & 282095 & 235521 & 60.5 & 59.7 \\
\hline \multicolumn{7}{|l|}{ (4) Marginal values } \\
\hline P 10 & 74641 & 74653 & 98426 & 104606 & 31.9 & 40.1 \\
\hline P 50 & 158153 & 136253 & 233386 & 210192 & 47.6 & 54.3 \\
\hline P 90 & 289223 & 231896 & 439933 & 369810 & 52.1 & 59.5 \\
\hline
\end{tabular}


that average inequality in Oslo, measured by the Gini coefficient, grew almost exactly at the same pace as income after tax for all households. By and large, the same holds for changes at the national level. But then the subsequent panels point towards two striking differences compared to Table 1. One relates to the richest groups, or more precisely, the rich and the super-rich. The latter distinction cannot be discerned directly from Table 2, but it is easily deduced from a comparison of panel 2, 3 and 4. Panel 2 shows that the top decile in Oslo increased its share of the total income by $34.5 \%$ between 1986 and 1996. The average income of the same decile, however, more than doubled. In conformity with the general picture, a similar but less marked trend applies for Norway as a whole. Turning to the bottom decile, we observe a gap between two types of indices. As shown in panel 2, there is a considerable decline in the share of all incomes, respectively $27 \%$ in Oslo and $21 \%$ in Norway. But as panel 3 brings out, there is no reduction in average income. Instead, we notice average increases in real income by 18\% (Oslo) and 26\% (Norway). Although these are moderate improvements, they do strengthen the proposition that students are a special group. Overall, income inequality in Oslo has grown at a pace that resembles the change in Stockholm (cf. Borgegård et al., 1998). Poor households with a firm and regular connection to the labour market, however, have only suffered relative losses. Recalling the fact that Oslo is one of the most expensive cities in Europe, such losses should not be neglected. But for what comfort it might bring, the social transformation seems less gloomy than earlier indicated.

So far, the account tells us nothing about individual income. In much contemporary literature, the argument leads from economic restructuring to the individual distribution of earnings and further to the household distribution of income. Briefly, two of the approaches discussed in this paper, the polarization and mismatch theses, emphasize the first link and make light of the second. The welfare state thesis provides an opposite perception, although with the addition that welfare states have to be financed, and that employment enables people to improve their socio-economic position. 'Productivism' is surely an important aspect of Scandinavian politics, and at least in Norway it has been strengthened over the last decade. Both the low-wage policies and observations made at the national level (Barth \& Kongsgården, 1996; Høgsnes, 1999) suggest a broad stability in the individual distribution of wages. A crucial question is, though, whether the rapidly restructuring economy of Oslo deviates from the national trajectory.

Some of the answer is provided in Table 3. According to polarization theory, we might expect that labour market functions and employment relations are strongly associated with hours of work. Part-time jobs occur frequently within consumption services, whereas manufacturing industries, primary industries and a large part of the public sector are typically based on full-time and year-round employment. It is thus a familiar pattern, consistent with the argument of Saskia Sassen, when wage inequality among part-time workers grows at a significant pace in Oslo. For people working 20-29 hours per week, the Gini coefficient rose by $6 \%$ during $1993-1998$, compared to $0.5 \%$ at the national level. Admittedly, these figures could partly reflect developments within the public sector, or changes in working hours rather than income. But as borne out by Table 3, there are widening inequalities even among people in full employment. By and large, the results challenge some of the bright metaphors in the welfare state literature, for instance the 'manna from heaven hypothesis' proposed by Richard Freeman. ${ }^{6}$ The evidence of convergence rather than divergence is further substantiated in the distribution of market income (Table 4), although the change is smaller than expected. Both earlier research and macro-economic indicators point towards capital incomes as a decisive source of rising inequality. However, in the course of 1998 the Norwegian economy started to cool off. Growth in non-oil exports slowed down, oil prices plunged, capital outflow soared and the index of shares dropped by 27\% within a few months (St.meld., 1998-1999; OECD, 1999). These signs of 'unwinding' may have slackened the trend towards income dispersion. 
Table 3. Dispersion of wages in Oslo and Norway measured by the Gini coefficient, 1993 and 1998, deflated to NOK 1993

\begin{tabular}{|c|c|c|c|c|c|c|}
\hline & \multicolumn{2}{|c|}{1993} & \multicolumn{2}{|c|}{1998} & \multicolumn{2}{|c|}{ Percentage change } \\
\hline & Oslo & Norway & Oslo & Norway & Oslo & Norway \\
\hline $\begin{array}{l}\text { Working less than } \\
20 \text { hours per week }\end{array}$ & 0.41597 & 0.38100 & 0.43546 & 0.38934 & 4.7 & 2.2 \\
\hline $\begin{array}{l}\text { Working 20-29 hours } \\
\text { per week }\end{array}$ & 0.28652 & 0.24896 & 0.30453 & 0.25027 & 6.3 & 0.5 \\
\hline $\begin{array}{l}\text { Working more than } \\
30 \text { hours per week }\end{array}$ & 0.24954 & 0.23313 & 0.26347 & 0.23999 & 5.6 & 2.9 \\
\hline $\begin{array}{l}\text { Men working more than } \\
30 \text { hours per week }\end{array}$ & 0.25996 & 0.23087 & 0.27544 & 0.23937 & 6.0 & 3.7 \\
\hline $\begin{array}{l}\text { Women working more } \\
\text { than } 30 \text { hours per week }\end{array}$ & 0.19876 & 0.19457 & 0.21358 & 0.20043 & 7.5 & 3.0 \\
\hline
\end{tabular}

Source: The Register of Income merged with the Register of Employment.

Table 4 also shows marked differences between non-Western immigrants and the remaining population. It takes more detailed measures to determine the exact importance of inequality within groups ('within-group effects') and inequality between groups ('betweengroup effects'). It is noteworthy, though, that market income inequality among non-Western immigrants in Oslo increased substantially over the 1993-1998 period: the Gini coefficient rose by 3.2 percentage points from a level that even in 1993 was well beyond Norwegian notions of equality. During these years the share of non-Western immigrants in the workforce increased from $8 \%$ to almost $12 \%$. Thus, it appears that changes in the personal income distribution have been driven by large and increasing differences in terms of ethnic background. These differences are also significant in explaining the widening gap between Oslo and the nation as a whole. To be sure, this is a descriptive and 'second-level' analysis. It says nothing about the roots of relative inequality.

I will now move on to the polarization issue. To repeat, this is a distinct analytical

Table 4. Gini coefficients for market income (wages, incomes from self-employment and capital incomes) in Oslo and Norway, 1993 and 1998, deflated to NOK 1993, students excluded in all groups

\begin{tabular}{|c|c|c|c|c|c|c|}
\hline & \multicolumn{2}{|c|}{1993} & \multicolumn{2}{|c|}{1998} & \multicolumn{2}{|c|}{ Percentage change } \\
\hline & Oslo & Norway & Oslo & Norway & Oslo & Norway \\
\hline Men & 0.4747 & 0.3909 & 0.4783 & 0.3907 & 0.8 & -0.1 \\
\hline Women & 0.3916 & 0.4002 & 0.4044 & 0.4023 & 3.2 & -0.6 \\
\hline $\begin{array}{l}\text { Men working more than } \\
30 \text { hours per week }\end{array}$ & 0.3268 & 0.2594 & 0.3426 & 0.2685 & 4.8 & 3.5 \\
\hline $\begin{array}{l}\text { Women working more } \\
\text { than } 30 \text { hours per week }\end{array}$ & 0.2182 & 0.1996 & 0.2249 & 0.2018 & 3.0 & 1.1 \\
\hline $\begin{array}{l}\text { Norwegians and Western } \\
\text { immigrants }\end{array}$ & 0.4456 & 0.4171 & 0.4479 & 0.4162 & 0.5 & -0.2 \\
\hline Non-western immigrants & 0.5028 & 0.5124 & 0.5351 & 0.5300 & 6.4 & 3.4 \\
\hline
\end{tabular}

Source: The Register of Income merged with the Register of Employment and the Register of Immigrants. 
Table 5. Distribution of households by decile, income after tax deflated by the rate of inflation and median income, Oslo and Norway 1986 and $1996(E=0.5)$

\begin{tabular}{|c|c|c|c|c|c|c|c|c|}
\hline \multirow[b]{3}{*}{ Decile } & \multicolumn{4}{|c|}{ Deflated by the rate of inflation } & \multicolumn{4}{|c|}{$\begin{array}{l}\text { Deflated by the change } \\
\text { in median income }\end{array}$} \\
\hline & \multicolumn{2}{|c|}{ Oslo } & \multicolumn{2}{|c|}{ Norway } & \multicolumn{2}{|c|}{ Oslo } & \multicolumn{2}{|c|}{ Norway } \\
\hline & 1986 & 1996 & 1986 & 1996 & 1986 & 1996 & 1986 & 1996 \\
\hline 1 & 10 & 10.1 & 10 & 8.8 & 10 & 11.9 & 10 & 11.3 \\
\hline 2 & 10 & 11.2 & 10 & 9.0 & 10 & 13.0 & 10 & 10.6 \\
\hline 3 & 10 & 11.2 & 10 & 9.1 & 10 & 11.6 & 10 & 9.9 \\
\hline 4 & 10 & 8.2 & 10 & 9.9 & 10 & 10.2 & 10 & 9.0 \\
\hline 5 & 10 & 8.9 & 10 & 9.3 & 10 & 7.8 & 10 & 9.1 \\
\hline 6 & 10 & 10.2 & 10 & 9.9 & 10 & 11.7 & 10 & 9.7 \\
\hline 7 & 10 & 8.1 & 10 & 10.4 & 10 & 7.2 & 10 & 10.7 \\
\hline 8 & 10 & 8.6 & 10 & 10.5 & 10 & 7.2 & 10 & 9.8 \\
\hline 9 & 10 & 9.7 & 10 & 11.2 & 10 & 8.7 & 10 & 9.8 \\
\hline 10 & 10 & 13.9 & 10 & 11.8 & 10 & 10.7 & 10 & 10.0 \\
\hline
\end{tabular}

Source: The National Survey of Income and Wealth.

phenomenon. Rising inequality may or may not reflect polarization. Is there a redistribution of people, and if so, is the dumb-bell a proper representation?

\section{Social Divisions in Oslo}

Table 5, which is based on income after tax, offers the immediate impression that the middle population of Oslo is shrinking, although slowly. The number of households falling into decile 4-8 was reduced by approximately 6 percentage points during 1986-1996 according to both measures, compared to $0-2$ percentage points for the whole of Norway. Moreover, as one would expect from the fact that students are included, there is a certain downward trend in these data, especially when the cut-off points are deflated by median income rise. For this period, the latter deflator is probably a better choice than the rate of retail price inflation. Given that median income rose by $54 \%$ and retail prices by $44 \%$, there is a danger that changes in the shape of the distribution are confounded with income improvements across the board.

A similar story is presented in Table 6. As in Table 2, the figures relate to market income. The period of analysis is 1986-1996, and only households with a fully employed head are counted. In broad outline, examining 'the bottom', 'the middle' and 'the top', there is a redistribution downwards in Oslo which is not replicated at the national level. Bearing in mind the distribution of incomes, one might be tempted to conclude that Oslo is a thing apart, a 'winner takes all society'. Overall, Norway is marked by a far better balance between the distribution of incomes and the number of rich households.

The second set of data, however, provides a different picture. Table 7 reports the changing distribution of full-time male workers across market income for the period 1993-1998. A remarkable upward shift emerges both for Oslo and Norway as a whole. At both levels, decile 1-5 decreased, whereas decile 6-10 grew in a fan-shaped pattern, that is, increasingly stronger as we move up the ladder. What we see here, is apparently a corroboration of the mismatch thesis: individuals are redistributed in accordance with the proposition that high skills and education dominate the new service economy. Still, some essential questions remain: Why is a different pattern observed for the period 1986-1996? Is the trend causally related to the 
Table 6. Distribution of households with a fully employed 'head' by decile, market income deflated by the rate of inflation and median income, Oslo and Norway 1986 and $1996(E=0.5)$

\begin{tabular}{|c|c|c|c|c|c|c|c|c|}
\hline \multirow[b]{3}{*}{ Decile } & \multicolumn{4}{|c|}{ Deflated by the rate of inflation } & \multicolumn{4}{|c|}{$\begin{array}{l}\text { Deflated by the change } \\
\text { in median income }\end{array}$} \\
\hline & \multicolumn{2}{|c|}{ Oslo } & \multicolumn{2}{|c|}{ Norway } & \multicolumn{2}{|c|}{ Oslo } & \multicolumn{2}{|c|}{ Norway } \\
\hline & 1986 & 1996 & 1986 & 1996 & 1986 & 1996 & 1986 & 1996 \\
\hline 1 & 10 & 11.8 & 10 & 10.6 & 10 & 13.2 & 10 & 12.7 \\
\hline 2 & 10 & 11.0 & 10 & 8.0 & 10 & 12.7 & 10 & 9.4 \\
\hline 3 & 10 & 10.0 & 10 & 8.1 & 10 & 11.2 & 10 & 9.2 \\
\hline 4 & 10 & 9.1 & 10 & 7.6 & 10 & 9.1 & 10 & 8.3 \\
\hline 5 & 10 & 6.1 & 10 & 9.6 & 10 & 7.5 & 10 & 10.5 \\
\hline 6 & 10 & 8.6 & 10 & 9.0 & 10 & 7.9 & 10 & 9.3 \\
\hline 7 & 10 & 11.1 & 10 & 11.5 & 10 & 10.5 & 10 & 11.1 \\
\hline 8 & 10 & 9.8 & 10 & 10.9 & 10 & 10.4 & 10 & 9.6 \\
\hline 9 & 10 & 11.0 & 10 & 10.3 & 10 & 8.0 & 10 & 8.5 \\
\hline 10 & 10 & 11.6 & 10 & 14.5 & 10 & 9.4 & 10 & 11.4 \\
\hline
\end{tabular}

Source: The National Survey of Income and Wealth.

changing nature of occupations? What are the effects of taxes and transfers? Is there a similar redistribution of households? I await the results of further research with interest. Meanwhile, it might be pertinent to repeat that the Norwegian economy performed extremely well in the mid-1990s. This suggests that a skill-based explanation is inadequate, to say the least.

Adding complexity, Table 8 shows a pattern of almost perfect symmetrical polarization for non-Western immigrants from 1993 to 1998 . The six mid deciles declined, adjusted for retail prices, with 15 percentage points in the case of Oslo and 13 percentage points in the case of Norway. The asymmetric polarization reported in Table 7 is thus confined to Norwegians and Western immigrants.

Table 7. Distribution of full-time male workers by decile, market income deflated by the rate of inflation and median income, Oslo and Norway 1993 and 1998

\begin{tabular}{|c|c|c|c|c|c|c|c|c|}
\hline \multirow[b]{3}{*}{ Decile } & \multicolumn{4}{|c|}{ Deflated by the rate of inflation } & \multicolumn{4}{|c|}{$\begin{array}{l}\text { Deflated by the change } \\
\text { in median income }\end{array}$} \\
\hline & \multicolumn{2}{|c|}{ Oslo } & \multicolumn{2}{|c|}{ Norway } & \multicolumn{2}{|c|}{ Oslo } & \multicolumn{2}{|c|}{ Norway } \\
\hline & 1993 & 1998 & 1993 & 1998 & 1993 & 1998 & 1993 & 1998 \\
\hline 1 & 10 & 8.1 & 10 & 7.2 & 10 & 7.8 & 10 & 6.9 \\
\hline 2 & 10 & 6.1 & 10 & 4.9 & 10 & 5.6 & 10 & 4.2 \\
\hline 3 & 10 & 6.9 & 10 & 6.5 & 10 & 6.3 & 10 & 5.8 \\
\hline 4 & 10 & 8.0 & 10 & 8.1 & 10 & 7.5 & 10 & 7.5 \\
\hline 5 & 10 & 9.8 & 10 & 9.5 & 10 & 9.4 & 10 & 9.1 \\
\hline 6 & 10 & 10.7 & 10 & 10.7 & 10 & 10.8 & 10 & 10.6 \\
\hline 7 & 10 & 11.4 & 10 & 11.9 & 10 & 11.8 & 10 & 12.1 \\
\hline 8 & 10 & 11.9 & 10 & 13.1 & 10 & 12.3 & 10 & 13.8 \\
\hline 9 & 10 & 12.4 & 10 & 13.5 & 10 & 12.9 & 10 & 14.4 \\
\hline 10 & 10 & 14.7 & 10 & 14.7 & 10 & 15.6 & 10 & 15.6 \\
\hline
\end{tabular}


Table 8. Distribution of non-Western immigrants by decile, market income deflated by the rate of inflation and median income, students excluded, Oslo and Norway 1993 and 1998

\begin{tabular}{|c|c|c|c|c|c|c|c|c|}
\hline \multirow[b]{3}{*}{ Decile } & \multicolumn{4}{|c|}{ Deflated by the rate of inflation } & \multicolumn{4}{|c|}{$\begin{array}{l}\text { Deflated by the change } \\
\text { in median income }\end{array}$} \\
\hline & \multicolumn{2}{|c|}{ Oslo } & \multicolumn{2}{|c|}{ Norway } & \multicolumn{2}{|c|}{ Oslo } & \multicolumn{2}{|c|}{ Norway } \\
\hline & 1993 & 1998 & 1993 & 1998 & 1993 & 1998 & 1993 & 1998 \\
\hline 1 & 10 & 15.6 & 10 & 16.1 & 10 & 15.6 & 10 & 16.0 \\
\hline 2 & 10 & 10.4 & 10 & 8.5 & 10 & 10.5 & 10 & 8.5 \\
\hline 3 & 10 & 7.6 & 10 & 7.1 & 10 & 7.6 & 10 & 7.0 \\
\hline 4 & 10 & 7.5 & 10 & 7.8 & 10 & 7.3 & 10 & 7.7 \\
\hline 5 & 10 & 7.0 & 10 & 7.4 & 10 & 6.8 & 10 & 7.2 \\
\hline 6 & 10 & 7.1 & 10 & 7.7 & 10 & 6.9 & 10 & 7.5 \\
\hline 7 & 10 & 6.7 & 10 & 7.6 & 10 & 6.5 & 10 & 7.4 \\
\hline 8 & 10 & 9.3 & 10 & 9.7 & 10 & 9.1 & 10 & 9.4 \\
\hline 9 & 10 & 11.8 & 10 & 12.2 & 10 & 11.7 & 10 & 12.3 \\
\hline 10 & 10 & 16.9 & 10 & 15.8 & 10 & 18.1 & 10 & 16.9 \\
\hline
\end{tabular}

Source: The Register of Income merged with the Register of Employment.

\section{Summary and Conclusions}

The empirical results above are difficult to reconcile with existing theoretical knowledge. First, contrary to the expectation provided by welfare state theory, several indicators point in the direction of rising income inequality. With all its economic well-being, Oslo stands out not as a case of persistent egalitarianism but rather as a case of flexible distributive adjustment. In the period 1986-1996, the Gini coefficient for the distribution of equivalent household income after tax increased by $35 \%$. This figure drops to $30.5 \%$ when taxes and transfers are excluded and the analysis is otherwise restricted to households with a fully employed head. Earlier suggestions that household formation and part-time work among students are important factors of change (Wessel, 1999) should therefore be moderated. Other factors seem to carry greater weight. The paper also demonstrates growing inequality in the personal distribution of income during 1993-1998. Despite some shortcomings of the data, they do suggest that ethnicity is central to the redistribution taking place in Oslo as well as to the widening gap between Oslo and the whole of Norway. In Oslo, there is almost no change in the distribution of market income among Norwegians/Western immigrants. Non-Western immigrants, however, experienced a rather steep increase in the Gini coefficient. A less surprising finding is that wage dispersion contributes to additional inequality in Oslo. At this point, the paper provides counter-evidence to the suggestion that only capital income matters.

The picture pertaining to social differentiation is rather mixed. Beginning with Oslo, there is a weak increase of households in the three bottom deciles during 1986-1996. None of the models presented in section two depicts downgrading as a dominant process, but if anything, such a pattern ties in with a radical version of polarization theory. ${ }^{7}$ The second set of data, however, shows a distinct upward shift in the distribution of full-time workers from 1993 to 1998. This would appear to corroborate the relevance of mismatch theory, and it is also in conformity with empirical analyses from New York (Angelo, 1995) and London (Hamnett \& Cross, 1998). But then again, analysing the distribution of non-Western immigrants, an almost perfect symmetrical polarization emerges. After adjusting the segments for retail price inflation, I found a movement of workers towards high- and low-income positions, generating 
the U-shaped distribution described by Saskia Sassen. A fairly similar pattern is reported for Norway, which is indicative of most analyses in this paper: the direction of change in Norway corresponds roughly to that in Oslo. The gap between the two scales is one of extent rather than shape. An important exception, though, is that the top embraces less people in Oslo than it does in Norway as a whole.

Several implications can be drawn from these results. To start with, there is clearly a huge need for disaggregated analyses, particularly analyses containing employment information. In making comparisons between branches and sectors, it is important to be careful about starting and ending dates. The analysis conducted here applies the sources that are available in Norway for the present. Future enquiries should focus on three related issues: parallel changes at the individual and the household level, distributive effects of taxes and transfers, and, finally, effects of internal inequality versus movements between groups. Research along these lines has so far only been conducted at the national level. Particularly in a nation obsessed with the idea of regional equalization, there is much to be gained by looking more closely at the major cities.

An interesting theoretical implication arises from the difference between inequality measures and measures of polarization. The former evidence is tidy and continuous - containing few imprints of political intervention, industrial relations or cultural values. New reports support earlier knowledge, thus certifying the image of extensive change. Reports on polarization as well as reports on service production, poverty and segregation (cf. Hamnett, 1996; Kloosterman, 1996; Burgers, 1996; Hamnett \& Cross, 1998; Musterd \& Ostendorf, 1998; Rhein, 1998; Preteceille, 2000; Wessel, 2000) are very different. In these reports, divergence prevails. There is discussion as to how institutional influences should be theorized, but the overall message emerging from the literature is that 'politics matter'. How are we to explain that indicators of inequality, and only those, converge?

One part of the answer has already been touched upon. The polarization and mismatch theses accentuate dissimilar patterns of differentiation within the new service economy. Both of them, however, suggest a growth of income inequality. Thus, the relation between data and theory is not one-to-one but one-to-many: the aggregate outcome may result either from skills mismatch, demand side transformations or both. What is more, the mismatch between educational and occupational attainment can be defined in terms of too much education rather than too little. 'Overeducation' has been sparsely exposed in the literature, but it is surely an emerging phenomenon in certain countries. There is also a distinction between two types of demand side transformations, ${ }^{8}$ first an industrial shift towards low-productivity services (i.e. the 'Baumol cost-disease problem') and, secondly, an organizational shift towards casual and unsheltered jobs.

All of these changes have a bearing upon welfare politics. To some extent they may also, in the end, reflect political choices or subtle changes in pay norms. As recognized by Anthony Atkinson (1997, 1999), the relevance of norms applies both to market decisions and to the distributive generousness of governments. Atkinson stresses the lack of long-run stability in the evolution of income inequality. At the national level, and over a period of 20-30 years, the pattern is not one of uniform change, but rather one of diversity. This applies even to neighbour nations with considerable cross-border economic flows (Atkinson, 1999). Still, looking at the latest period, a less varied picture emerges. In the period from the mid-1980s to the mid-1990s, 19 of 20 OECD countries saw an increase in income inequality (OECD, 1998, p. 36). Even more important is the fact that analyses of major European cities present similar stories: a growth of income inequality has been reported for London (Hamnett, 1996; Hamnett \& Cross, 1998) the Randstad (Hamnett, 1994a), Paris (Body-Gendrot, 2000), Hamburg (Friedrichs, 1998), Brussels (Kestelot, 1998) and Stockholm (Borgegård et al., 1998). 
This is of course not to suggest that government interventions are negligible. The political element may be seen partly as a matter of incentives and partly as a matter of reduced choice. In general, these categories are likely to vary across clusters of welfare states. As for Scandinavia, the latter category is probably more critical than the former. Borrowing a concept from Raymond Boudon, I have recently suggested that increasing inequality in the social democratic context approaches a 'closed process', where technological, economic and organizational elements combine to reduce the area of real choice (Wessel, 2000). If I am right, it is not sufficient to document the prevalence of a certain welfare state regime (Hamnett, 1996) or of national idiosyncrasies within the welfare state machinery (Murie, 1998). Instead, we have to study how actors within the welfare state are blocked from selecting options that would efficiently counter-balance market impulses towards increasing inequality.

One significant limitation within Norwegian social democracy is the pressure to maintain a high level of productivity. With a strong emphasis upon full employment, a continuous commitment to generous benefits and a costly education system, the issue in Norway is whether the economy grows at a healthy pace. A second structural constraint has a purely endogenous nature. Due to the corporate bargaining system, the closed process of rising inequality is channelled more easily through capital incomes and fringe benefits than through normal earnings. However, if the corporate system is weakened, whether as a result of industrial restructuring or institutional erosion, open premiums may be on the increase. The Norwegian system of labour relations is deeply rooted, but during recent years there have been clear signs of union rivalry, fragmentation and, not least, a change of hegemony from unions representing the manufacturing industries to unions representing academics and well-educated professionals. These emerging changes are likely to increase wage dispersion in the future.

Although I find this approach inspiring, some bothering questions remain. How, for instance, are we to explain the changes at the very top of the income distribution in Oslo?

'The economics of superstars' suggests, first, that technological progress favours men and women with extraordinary abilities and, second, that talents are geographically concentrated; "The best doctors, lawyers and professional athletes should be found more frequently in larger cities" (Rosen, 1981, p. 856). Possibly so, but for my part I place more faith in the importance of social networks. The distinction between people basing their position on cultural and economic capital has obviously increased (Rosenlund, 2000). Economic success is thus less cushioned by 'good taste' and normative obligations than earlier. In turn, we see a range of behavioural and structural changes, such as excessive financial wheeling and dealing, conspicuous consumption and a more fragmented pattern of social mobility. A somewhat different explanation emphasizes the global character of business relations. Norwegian top leaders, who tend to live in Metropolitan Oslo, are regularly confronted with astronomical earnings among foreign colleagues. This frame of reference is strengthened by a lack of social contact with the general population and, reversed, by mutual participation in administrative bodies (Hernes, 2000). Quite another matter is that only a handful of these leaders 'play in the Champions league' (Hernes, 2000, p. 85). A voice from the business elite has retorted that top leaders need to have exceptional earnings in order to reduce the number of additional commissions (Reinås, 2000). What an illustration of business-related life tracks!

\section{Acknowledgements}

I would like to thank Eric Clark, Hans Thor Andersen, Geir Høgsnes and an anonymous referee for their constructive comments on an early draft of this paper. 


\section{Notes}

1. In addition, the debate touches on the relationships between economic change, social inequality and patterns of segregation.

2. The municipality of Oslo has a population of approximately 510,000 inhabitants, compared to approximately 1 million inhabitants in the Oslo region. I can not rule out the possibility that intra-urban mobility has contributed to increasing social differentiation in central areas of the region. The function of Oslo as a 'transit harbour', however, was far more pronounced in the 1960s and 1970s. Important stabilising phenomena are gentrification, increasing number of part-time students, changing housing preferences and a low level of housing production.

3. Kloosterman (1996) and Hamnett and Cross (1998) apply a similar distinction. Economists, on the other hand, tend to define polarisation as a condition. Consequently, they frequently refer to 'growing polarisation' and 'declining polarisation'. Being used to the double meaning of 'segregation', I see no immediate problems with this differential practice.

4. After massive strike actions and a general lockout in 1986, a 'no wage increase' agreement was struck between the federations of trade unions and employers in 1987. The following seven years were all marked by low nominal wage increases and a low-wage profile.

5. A minor adjustment took place in 1987 when certain fringe benefits were added to taxable income. Five years later, in 1992, a major revision introduced lower rates of depreciation for self-employed tradesmen and a total exemption of personal taxation on dividends to shareholders.

6. This hypothesis states that Norway's oil wealth permits it to fund greater state intervention than other countries. Freeman (1997, p. 44) concludes that the hypothesis is only partly correct, because the various types of intervention reflect political choices.

7. 'Deskilling theorists' hold that job growth occurs at both ends of the distribution, but with deskilling and downgrading as the main process. It is worth noting that the pattern in Oslo is not a uniform downgrading. Dependent upon the choice of deflator and the inclusion of part-time workers, there is a marginal increase of households at the top. But it is also crucial that the measure is not related to specific occupations, and that the unit of analysis is somewhat inapt.

8. Skills mismatch is often seen as a result of demand side changes, particularly related to increased trade flows. Richard Freeman (1997, p. 28) has formulated the thrust as follows "... free trade makes worldwide factor endowments rather than domestic labour conditions the determinant of the relative and real pay of factors of production in trading countries".

\section{References}

Andersen, H.T. and Clark, E. (2001) Does Welfare Matter? Ghettoisation in the Welfare State. Lund: Preliminary paper.

Angelo, L. (1995) Marching to its own drummer. Why wage trends in New York City have diverges from the nation, Urban Affairs Review, 31, pp. 104-119.

Atkinson, A.B. (1997) Bringing income distribution in from the cold, The Economic Fournal, 107, pp. 297-321.

AtKinson, A.B. (1999) Is Rising Income Inequality Inevitable? A Critique of the Transatlantic Consensus, WIDER Annual Lectures 3. UNU World Institute for Development Economic Research

Barth, E. and Kongsgården, M. (1996) Lønnsspredningen i Norge 1991-1995, Søkelys på arbeidsmarkedet, pp. 167-173.

Body-Gendrot, S. (2000) The Social Control of Cities. A Comparative Perspective. Oxford: Blackwell.

Borgegård, L.E., Andersson, E. and HJort, S. (1998) The divided city? Socio-economic changes in Stockholm metropolitan area, 1970-74, in S. Musterd and W. Ostendorf (Eds) Urban Segregation and the Welfare State. Inequality and Exclusion in Western Cities, pp. 206-222. London and New York: Routledge.

Buck, N. (1986) Social and economic change in contemporary Britain: the emergence of an urban underclass?, in E. Mingione (Ed.) Urban Poverty and the Underclass, pp. 277-298. Oxford and Cambridge, MA: Blackwell.

Burgers, J. (1996) No polarisation in Dutch cities? Inequality in a corporatist country, Urban Studies, 33, pp. 99-105. 
Castells, M. (1998) The Information Age: Economy, Society and Culture. Volume 3: End of Millenium. Oxford: Blackwell.

Dølvik, J., BrÅten, M., Longva, F. and Steen, A.H. (1997) Norwegian labour market institutions and regulations, in J.E. DølvIK and A.H. STEEN (Eds) Making Solidarity Work? The Norwegian Labour Market Model in Transition, pp. 51-110. Oslo: Scandinavian University Press.

EPLAND, J. (1998) Endringer i fordelingen av husholdningsinntekt 1986-96, Rapport 98/17. Oslo: Statistisk sentralbyrå.

EPLAND, J. and Kirkeberg, M. (1999) Inntekt og skatt for peroner og husholdninger, in SSB, Inntekt, skatt og overforinger 1999. Oslo.

Esping-Andersen, G. (1993) Changing Classes: Stratification and Mobility in Postindustrial Societies. London: Sage.

Esping-Andersen, G. (1998) Social Foundations of Postindustrial Economies. Oxford: Oxford University Press.

Esteban, J.M. and Ray, D. (1994) On the measure of polarization, Econometrica, 62, pp. 819-851.

Fainstain, S. (1997) The egalitarian city: the restructuring of Amsterdam, International Planning Studies, 2, pp. 295-314.

Freeman, R.B. (1997) Are Norway's solidaristic and welfare state policies viable in the modern global economy, in J.E. DøLviK and A.H. SteEn (Eds) Making Solidarity Work? The Norwegian Labour Market Model in Transition, pp. 17-50. Oslo: Scandinavian University Press.

Friedrichs, J. (1993) A theory of urban decline, Urban Studies, 30, pp. 907-917.

FrIEDRICHS, J. (1998) Social inequality, segregation and urban conflict: the case of Hamburg, in S. Musterd and W. Ostendorf (Eds) Urban Segregation and the Welfare State. Inequality and Exclusion in Western Cities, pp. 168-190. London and New York: Routledge.

Hamnett, G. (1994a) Social polarisation in global cities: theory and evidence, Urban Studies, 31, pp. $401-424$.

Hamnett, C. (1994b) Socio-economic change in London: professionalisation not polarisaton, Built Environment, 20, pp. 192-203.

Hamnett, C. (1996) Social polarisation, economic restructuring and welfare state regimes, Urban Studies, 33, pp. 1407-1430.

Hamnett, C. and Cross, D. (1998) Social polariation and inequality in London: the earnings evidence, 1979-95, Environment and Planning C: Government and Policy, 10, pp. 659-680.

Handcock, M.S., Morris, M. and Bernhardt, A.D. (1994) Economic inequality: new methods for new trends, American Sociological Reviewe, 59, pp. 205-219.

Harrison, B. and Bluestone, B. (1988) The Great U-turn. Corporate Restructuring and the Polarizing of America. New York: Basic Books.

Hegnar, T. (1999) Nytt fra forskningsfronten, Finansavisen, 31 August.

Hernes, G. (2000) Norge mellom grådighetskultur og jantelov, Horisont, 2, pp. 72-94.

Høgsnes, G. (1999) Krone for krone. Lonnsforhandlinger- og fordelinger. Oslo: Ad Notam, Gyldendal.

KASARDA, J. (1989) Urban industrial transition and the underclass, Annals of the American Academy of Political and Social Science, 501, pp. 26-47.

Kestelot, C. (1998) The geography of deprivation in Brussels and local development strategies, in S. Musterd and W. Ostendorf (Eds) Urban Segregation and the Welfare State. Inequality and Exclusion in Western Cities, pp. 126-147. London and New York: Routledge.

Kloosterman, R.C. (1996) Double Dutch: polarization trends in Amsterdam and Rotterdam after 1980, Regional Studies, 30, pp. 467-476.

KuzNets, S. (1955) Economic growth and income inequality, American Economic Review, 45, pp. 1-28.

Lehto, J. (2000) Different cities in different welfare states, in A. BAGNasco and P. LE Galės (Eds) Cities in Contemporary Europe, pp. 112-130. Cambridge: Cambridge University Press.

LEvy, F. and Murnane, R.J. (1992) US earnings levels and earnings inequality: a review of recent trends and proposed explanations, Fournal of Economic Literature, 30, pp. 1333-1381.

Murie, A. (1998) Segregation, exclusion and housing in the divided city, in S. Musterd and W. OstendDrf (Eds) Urban Segregation and the Welfare State. Inequality and Exclusion in Western Cities, pp. 495-516. London and New York: Routledge.

Murie, A. and Musterd, S. (1996) Social segregation, housing tenure and social change in Dutch cities in the late 1980s, Urban Studies, 33, pp. 495-516. 
Musterd, S. and Ostendorf, W. (Eds) (1998) Urban Segregation and the Welfare State. Inequality and Exclusion in Western Cities. London and New York: Routledge.

NOU (1992) En nasjonal strategi for okt sysselsetting i 1990-årene, 26. Oslo: Universitetsforlaget.

NOU (1993) Levekår i Norge. Er graset gront for alle?, 17. Oslo: Universitetsforlaget.

OECD (1998) Income distribution and poverty in selected OECD countries, ECO/WKP(98)2.

OECD (1999) Economic survey of Norway, February 1999. OECDs Economic surveys. http://www.OECD.ORG/ $\mathrm{ECO} /$ surv/esu-nor.htm

PAHL, R. (1988) Some remarks on informal work, social polarisation and the social structure, International Journal of Urban and Regional Research, 12, pp. 779-795.

Preteceille, E. (2000) Segregation, politics and class in large cities, in A. Bagnasco and P. Le Galès (Eds) Cities in Contemporary Europe, pp. 74-97. Cambridge: Cambridge University Press.

REINÅs, J. (2000) Lederlønn må sikre maksimal verdiskapning, Horiont, 2, pp. 38-49.

Rhein, C. (1998) Globalisation, social change and minorities in metropolitan Paris: the emergence of new class patterns, Urban Studies, 35, pp. 429-447.

RøDseth, T. (1977) Levekårsundersøkelsen. Inntektsfordeling i Norge. Oslo: NOU 1977:44, Universitetsforlaget. Rosen, S. (1981) The economics of superstars, The American Economic Review, 71, pp. 845-858.

Rosentund, I. (2000) Social Structures and Change: Applying Pierre Bourdieu's Approach and Analytic Framework. Working papers from Stavanger University College.

Sassen, S. (1991) The Global City. New York, London, Tokyo. Princeton, NJ: Princeton University Press.

Sassen, S. (1995) Cities in a World Economy. Thousand Oaks, CA: Pine Forge Press.

Sassen, S. (1998) Globalization and its Discontents. New York: New Press.

Silver, H. (1993) National conceptions of the new urban poverty: social structural change in Britain, France and the United States, International Journal of Urban and Regional Research, 17, pp. 336-354.

ST.MELD. (1998-1999) Utjamningsmeldinga. Om fordeling av inntekt og levekår $i$ Norge, 50.

Strøm, S., Wennemo, T. and Aaberge, R. (1993) Inntektsulikhet i Norge 1973-1990, Rapport 93/17. Oslo: Statistisk sentralbyrå.

Wessel, T. (1999) Ulikhet og levekår i storbyene. Oslo: NBI prosjektrapport 258.

Wessel, T. (2000) Social polarisation and socioeconomic segregation in a welfare state: the case of Oslo, Urban Studies, 37, pp. 1947-1967.

Wolfson, M.C. (1994) Conceptual issues in normative measurement. When inequalities diverge, American Economic Review, 84, pp. 353-358. 